\title{
CREATING A LOVABLE AND LIVABLE PUBLIC PLACE: A METHOD FOR AUGMENTING CONTEMPORARY BEHAVIOUR SETTINGS IN "WORLD HERITAGE LIST" HISTORIC JEDDAH (ALBALAD), SAUDI ARABIA
}

\author{
ABDULKADER ABDULRAHMAN ALGILANI \\ Department of Landscape Architecture, King Abdulaziz University, Saudi Arabia
}

\begin{abstract}
In an effort to prepare design schools' fresh graduates for historic preservation demands apparent in Saudi Arabia, the Department of Landscape Architecture at King Abdulaziz University made efforts to equip students with historic preservation skills, tools and knowhow. This is much needed to improve the conditions of the large number of historic sites prioritized in the country's Vision 2030. This paper discusses the method used in a socially concerned, historic preservation graduation project, which proposes augmenting publicly demanded contemporary functions and services to the "World Heritage List" inducted sector of Historic Jeddah ( البلد/AlBalad), Saudi Arabia. The aim of this exercise is to bring historic Jeddah back into contemporary Jeddah resident's living realm. That is crucial to sustain the historic town as a viable part of metropolitan Jeddah. To achieve this, the public was approached to list amenities and services they frequent in their daily lives. These were matched to pre-categorized historic places (buildings and open spaces), with consideration to international and local preservation and municipal classification and regulations. One has to mention that open spaces were absent from local categorization, and thus a method was devised to categorize them according to their own merit, surrounding buildings' historic values, and preservation categorizations. The project found the area capable of adaptive reusable buildings and open spaces. This is mainly due to the high number of historic and non-historic lower category buildings, surrounding the higher category monumental buildings. It also showed public interest in rediscovering the historic area of Jeddah (AlBalad). Not only that, but such schemes have the potential of improving longevity and sustainability of this historic urban fabric, by concisely infusing social and cultural activity, much needed to bring historic sites alive. Keywords: historic preservation, Jeddah (AlBalad), contemporary behavior settings, livable, landscape architecture.
\end{abstract}

\section{INTRODUCTION}

Major socioeconomic and urban changes has been launched in Saudi Arabia with the introduction of Vision 2030. A part of this is to empower local citizens to develop and utilize cultural assets for socio-economic benefits. Saudi design schools, among other institutions, are expected to assume the responsibility of preparing their fresh graduates for adaptive reuse of historic sites, and to expose them to the theoretical and scientific bases for such a skill. Realizing the urgency of the cause triggered the adaptive-reuse preservation type versus function matching method used for the student's graduation project method discussed herein, and produced at the Department of Landscape Architecture, Faculty of Environmental Design (now the Faculty of Architecture and Planning), King Abdulaziz University.

The purpose of the graduation project was to allocate behavior settings, that are of interest to contemporary Jeddah residents, within the "World Heritage List" inducted part of AlBalad, using ICOMOS approved standards. Historic sites were classified and matched to contemporary functions to produce livable places that might be "third places", as referred to by Oldenburg [1]. The theoretical backbone of this project is targeting the next step of the 
historic preservation efforts, currently in progress at AlBalad, and make it more attractive, both livable and lovable.

This paper discusses the methods used to collect data, categorize historic locations (buildings and open spaces), and match their contemporary functions to yield a suitable urban landscape design.

\section{LITERATURE REVIEW}

Jeddah, a cosmopolitan port of Saudi Arabia, with 3.4 million inhabitants [2], witnessed a large increase on its populations since the 1925 count of 16,000 AlBalad inhabitants [3]. For centuries, immigrants and migrants have colored historic Jeddah with a wide spectrum of culture, which then cross pollinated with the local culture, to produce the unique cosmopolitan "Jeddawi" culture, illustrated in multiple authors such as Alansari [4], Baqader and Alturki [5], Baeshen [6] and Baghaffar [7]. Jeddah's culture has always been inclusive and diverse, and that is the vessel used in this method to reintroduce the people of Jeddah to their heritage in a contemporary light.

This reintroduction is vital to assure cultural connections to the city's physical cultural core, and continuity of its non-physical culture, after the disconnect that it suffered post late 1970s [8], [9].

True to the belief of Tyler et al. historic preservation is a grass-root movement [10]. After decades of neglect, interest in AlBalad gained momentum during the early 2000s, driven by a strong internet-based movement, that utilized social media platforms (especially Facebook) to mobilize thousands of activists, of both genders and of all ages, to have their feet on AlBalad grounds, through a multiplicity of cultural activities. The first, and most prominent of these groups is "Jeddah's Heart Group" (مجموعة قلب جدة), established in 2011. This brought life back to AlBalad, through events, regular tours, and establishment of services through adaptive reuse, such as cafes, art galleries, multi-use cultural halls, antique shops etc. The success of such activities opened the doors wide to inject AlBalad's historic fabric with suitable services, that serve as magnets to attract the locals to their ancestral origin, to a familiar place they heard stories about. Stories of their older loved ones. This reassurance that comes from the familiar is a factor that this method in hand is depending on to elevate the frequency individuals visit to AlBalad. This method will augment familiar functions and services in familiar (personal) "place".

The rise of individual activities yielded annual events for years to follow, and drew interest of the country's main authority on historic preservation: The General Authority for Tourism and Antiquity, which made the effort to further elevate a part of AlBalad to a World Heritage Site. That placed Jeddah in the international cultural spotlight, and elevated its status nationally. Millions of Saudi Riyals were allocated for preserving its buildings, and laying the infrastructure needed for a proper historic site at this time and age. That included issuing a Royal Decree to restore 56 critically endangered historical buildings in Jeddah [11].

This effort must be guided to bring people back to AlBalad, otherwise it will be falling apart again due to neglect. Contemporary cultural values must be embraced, along with permanent inherited values, to appease the contemporary society; both will affect the behaviour in the streets [12], and all of AlBalad.

Research proved that historic sites can be livable (Allison and Peters [13]). That is why preservation efforts must not focus on individual building, but rather take a wholistic approach to historic preservation. It should include all urban units of historic urban fabrics [14], and non-monetary historic aspects in the preservation efforts. 


\section{METHOD}

In an attempt to find what service/utility is suitable for the historic AlBalad "World Heritage List" area, a mix-methodology method was used to collect and process data to achieve the goals of this project.

\subsection{Inquisitive enquiry}

The project needed to find magnets to attract local residents to AlBalad. There, a deliberate decision was made to list Jeddah residents everyday destination that suits the historic urban fabric. That should bring life to the historic urban fabric, with low impact services and functions.

To build a data base of popular functions desired by the residents of metropolitan Jeddah, an inquisitive enquiry, open ended question and answer, was used. Here, random locals were asked to list a week's worth of destinations they usually frequent, out of home and work. (Table 1) This should reveal their most visited places, and review the diversity of functions within their living realm. The reason for the weekly limitation is the scarcity of monthly visited destinations, and that annual visitation frequency is too scarce to serve the purpose of the project [15].

Table 1: Popular functions desired by residents of metropolitan Jeddah [16].

\begin{tabular}{|c|c|c|c|}
\hline $\begin{array}{l}\text { Social hub open } \\
\text { space units }\end{array}$ & $\begin{array}{l}\text { Educational and } \\
\text { cultural units }\end{array}$ & $\begin{array}{l}\text { Entertainment } \\
\text { units }\end{array}$ & Commercial units \\
\hline WIFI & $\begin{array}{l}\text { Historic and } \\
\text { cultural trails }\end{array}$ & Scenic trails & $\begin{array}{l}\text { Speciality coffee } \\
\text { shops }\end{array}$ \\
\hline Public toilets & Informative signage & $\begin{array}{l}\text { Livable open } \\
\text { spaces }\end{array}$ & Hotels \\
\hline Coffee shops & Museums & Social open spaces & Restaurants \\
\hline Social event halls & $\begin{array}{l}\text { Permanent } \\
\text { workshops }\end{array}$ & $\begin{array}{l}\text { Permanent } \\
\text { Activities }\end{array}$ & Attended parking \\
\hline Seasonal festivities & Crafts education & Coffee shops & Luxury brand shops \\
\hline & & Live shows & Craft and art shops \\
\hline
\end{tabular}

The collected data was found to fall under four categories: Social hubs (urban units), educational and cultural units, entertainment units, commercial units.

\subsection{Semi-structured interviews}

Secondary data was collected from various municipal agencies, including onsite urban units state, local municipal zoning, and preservation categories (all are recognized by The Jeddah Municipality). This database was essential for prescribing proper functions to suitable places.

\subsection{Data gap analysis}

A morphological study of the site showed two main types of places: buildings (officially classified and assigned preservation categories), and open spaces which are traditional plazalike open space units $(B a r h a(t))$ (mostly neglected and hardly classified, and none had preservation categorization). 
Both types were evaluated for this project purpose to fill the gap in official data collected. The evaluation criteria used and reason for selection are:

- $\quad$ Presence of facilities (support);

- Cultural value (historic value);

- Accessibility (access and linkage, equal opportunity);

- Residential habitation (ownership and sociability);

- Safety (comfort and image);

- Historic coherence of surroundings (integrity of AlBalad's image);

- Preservation category (contributing assists); and

- Official recognition of the unit's historic value (recognition).

Please see Tables 2 and 3 and Fig. 1 for evaluation results.

\subsection{Multi category data cross referencing}

Following the parent data gap, because not all open space unites are officially classified and assigned preservation categories by local authorities, a multi category evaluation system was devised to rank the suitability of all open space units for suggested development, this included the surrounding buildings preservation ranking, since all are contributing to the value of the open spaces they abode. To achieve this, the surrounding buildings preservation category was calculated as an average of values assigned to each building, that reflect the international preservation ranking categories.

The top part of Tables 2 and 3 further clarifies the open spaces evaluation (ranking) criteria, where one can find the value range for each of the open spaces' evaluating categories. The values of the $\mathrm{G}$ category are based on the 6-category system at which AlBalad's urban units are categorized for preservation purposes by the Jeddah Municipality.

As a result of the above ranking, all open space units (barhat) were assigned a land use category, that is based on its own merit, along with that of its surroundings.

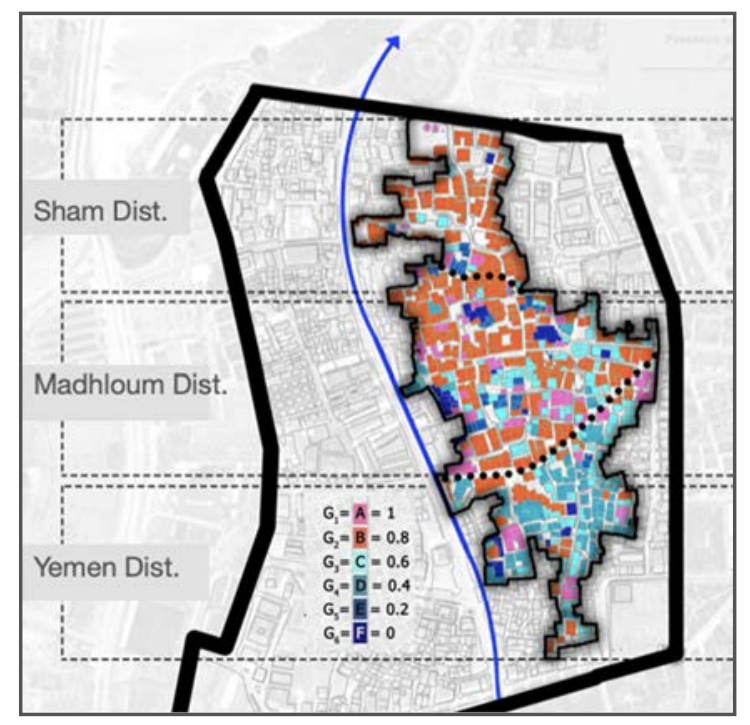

Figure 1: Official open space units classification [16]. 


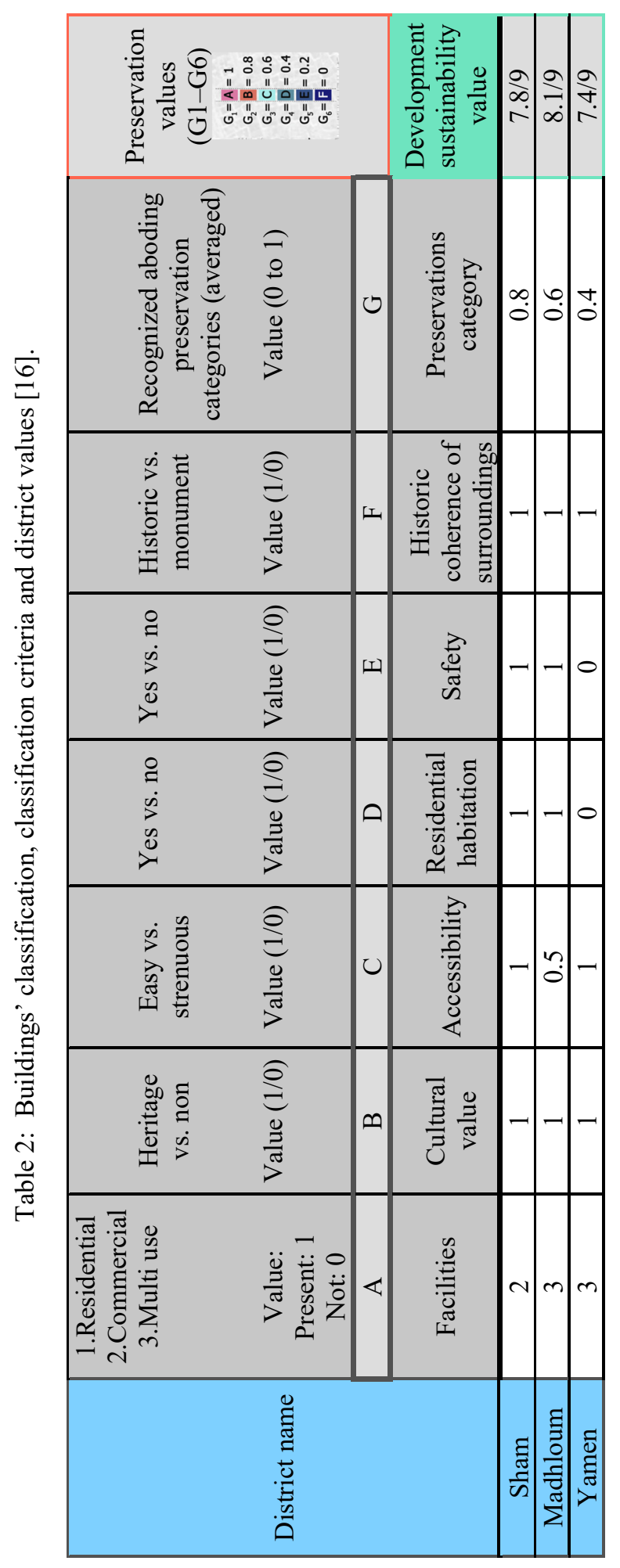




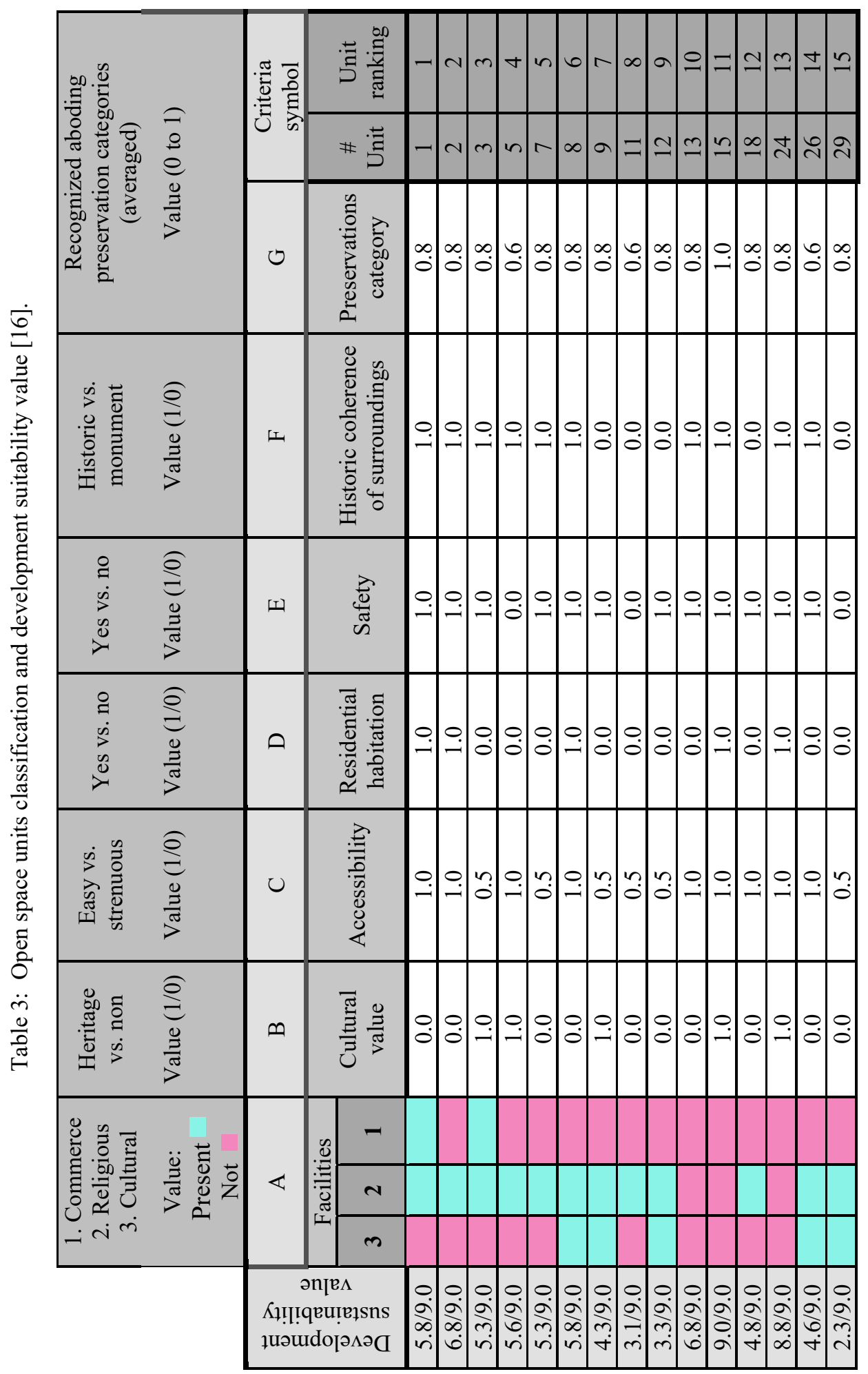




\subsection{Suitability analysis}

In this exercise, open space units were matched to four land use categories, classified from the popular functions desired by the residents. These suitability's are corresponding to the services desired by the Jeddah residences shown in Table 1. They are: social, educational and cultural, entertainment, and commercial. The spatial result of this suitability exercise is shown in Table 4 and Fig. 2.

To summarize, one can find the sequential flow of this project's method in Fig. 3. The different methods/techniques illustrated above were synchronized to achieve the graduation project whose method is discussed. It proved the success probability of adaptive reuse in AlBalad, by proving the possibility of successful function to space matching.

Table 4: Open space units classification and development suitability value [16].

\begin{tabular}{|c|c|c|c|c|c|c|c|c|}
\hline \multicolumn{2}{|c|}{ Social } & \multicolumn{2}{|c|}{$\begin{array}{l}\text { Education and } \\
\text { cultural }\end{array}$} & \multicolumn{2}{|c|}{ Entertainment } & \multicolumn{2}{|c|}{ Commercial } & \multirow[t]{2}{*}{ Criteria } \\
\hline High & Medium & High & Medium & High & Medium & High & Medium & \\
\hline Social & Religious & Religious & Social & $\begin{array}{c}\text { Commercial } \\
\text { and social }\end{array}$ & Social & Commercial & Social & A \\
\hline- & - & 1 & 0 & - & - & 1 & 0 & B \\
\hline 2 & 1 & 2 & 1 & 2 & 1 & 2 & 1 & $\mathrm{C}$ \\
\hline 1 & 0 & - & - & 1 & 1 & - & - & $\mathrm{D}$ \\
\hline 1 & 1 & 1 & 0 & 1 & 1 & 1 & 1 & $\mathrm{E}$ \\
\hline- & - & 1 & 0 & 1 & 0 & $\overline{-}$ & - & $\bar{F}$ \\
\hline $3-6$ & $1-2$ & - & - & $4-6$ & $1-3$ & $5-6$ & 4 & $\mathrm{G}$ \\
\hline \multicolumn{4}{|c|}{$\begin{array}{l}\text { Only open space units of high and } \\
\text { medium category values where fulfil } \\
\text { the four suitability categories. }\end{array}$} & $1-2$ & $3-4$ & $5-6$ & $7-9$ & \\
\hline & & & & Very low & Low & Medium & High & \\
\hline
\end{tabular}

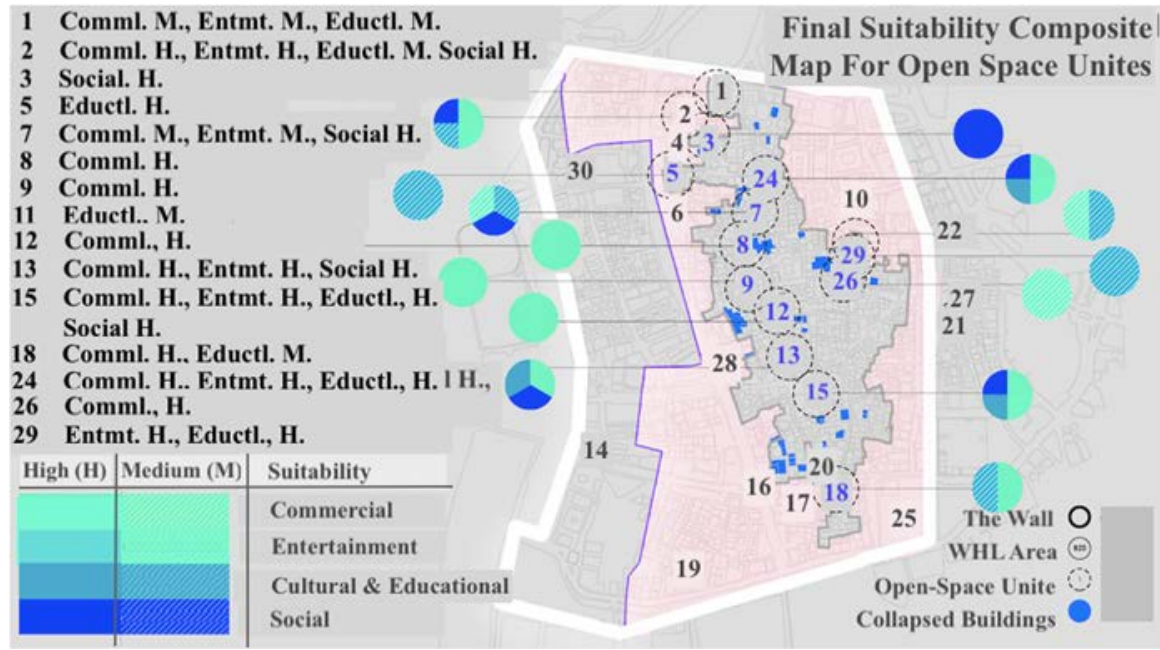

Figure 2: Composite suitability analysis map [16]. 


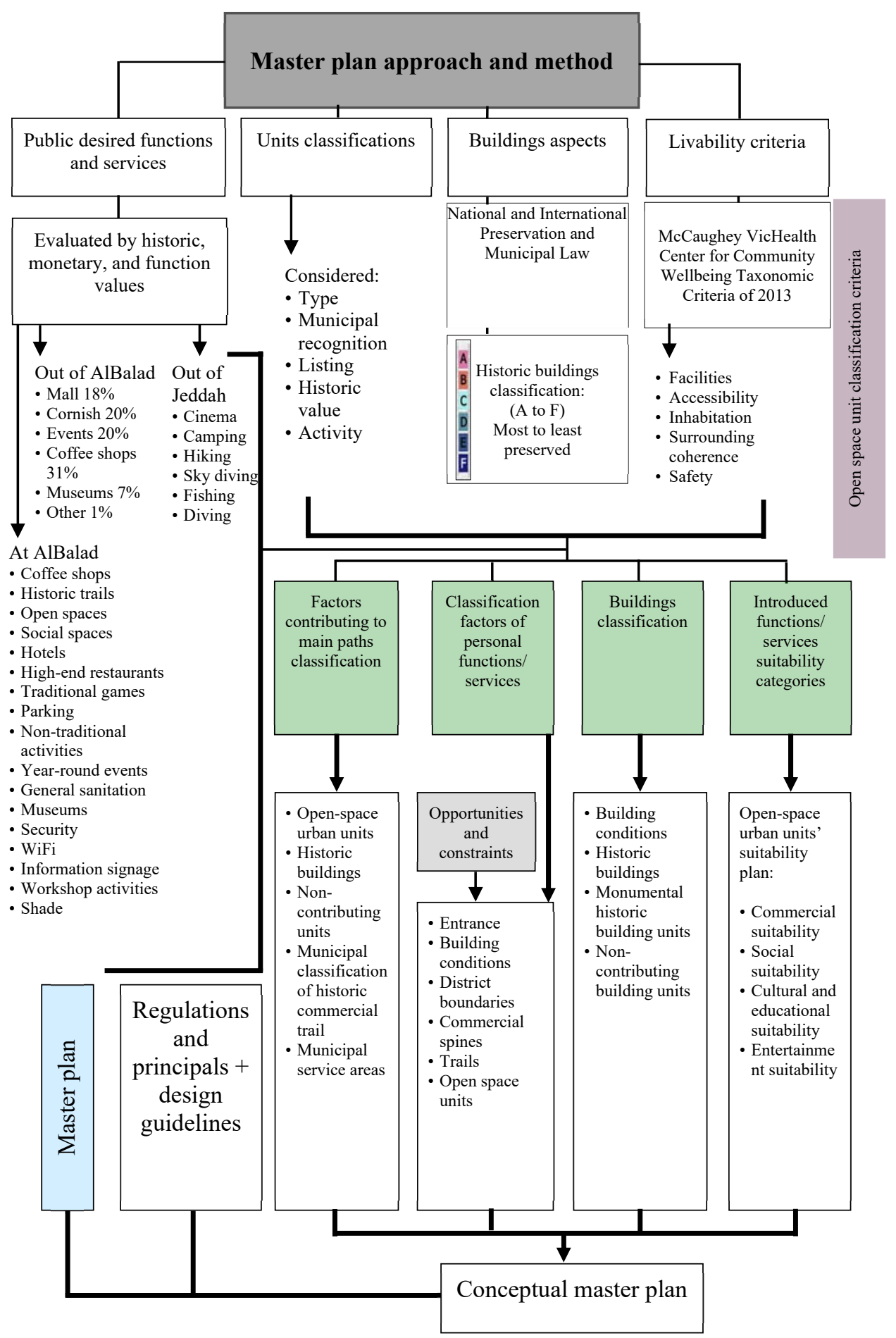

Figure 3: Project method and sequence [16]. 


\section{THE IMPACT OF GRASSROOTS' INITITAVES AT ALBALAD}

Almost a year after the conclusion of the graduation project, whose method is discussed here, the government announced a major AlBalad project. The current Historic Jeddah Project Management is converted to a rehabilitation program aiming at developing urban, economic, social, cultural, historic, and environmental components, along with providing all infrastructure and services to sustain its value [17].

Ashe was recommended to contact the authorities in charge with the hope he can utilize the knowledge he accumulated for the benefit of AlBalad, which he did.

\section{FINDINGS}

- The method proved the WHL indicted area capable of handling adaptive reuse, provided proper execution. This is due to the growing interest, and variation of existing preservation categories on site. That will allow the flexibility needed in adopting contemporary live style needs into the site at proper national and international standards.

- In evaluating open space units, it may have been worth to assign the highest building value, in oppose to averaging all buildings value. That may preserve the integrity of the monument on sight, and elevate the value of its surroundings.

- The suitability study showed that a particular space may have potentials for multiple land uses. That can be realized with better refinement of the spatial attributes, evaluation and ranking criteria. If managed, on can re-introduce a long gone Islamic, and sustainable concept of time distributed land use, which can be a contributing element to AlBalad's original narrative, image and brand.

- Data collected from random subjects may be more AlBalad friendly if the contributing subjects were sympathetic to the area. On the other hand, random selection clears data from self-censoring and preconception.

\section{ACKNOWLEDGEMENTS}

I must thank my former student, now graduate, Landscape Architect Mazen M. Ashe for offering information from his graduation project titled: How to Make AlBalad Spaces Livable, which I supervised and devised the method for. Utmost gratitude is due to all faculty members who taught this graduation studio of 2019.

\section{REFERENCES}

[1] Oldenburg, R., The Great Good Place: Cafés, Coffee Shops, Bookstores, Bars, Hair Salons, and other Hangouts at the Heart of a Community, Da Capo Press: Philadelphia, 2005.

[2] Saudi Arabian General Authority for Statistics, Population count of cities with more than 5000 inhabitants. www.stats.gov.sa/sites/de fault/files/census31-prim-05.pdf. Accessed on: 4 Apr. 2020. (In Arabic.)

[3] AlSaqqaf, A., Historic Jeddah: 536 native family representatives receives over a million local and international tourists. www.al-madina.com/article/352464. Accessed on: 4 Apr. 2020. (In Arabic.)

[4] Alansari, A., Historic Encyclopedia of Jeddah City, Knooz `Alma’rifah Press: Jeddah, 2018. (In Arabic.)

[5] Baqader, A. \& Alturki, T., Jeddah the City of Prosperity and Hardship, Dar Alshorooq Press: Cairo, 2006. (In Arabic.)

[6] Baeshen, L., Folktales From Saudi Arabia, Alruwad: Jeddah, 2002.

[7] Baghaffar, H., Alwalaya Shelter, Dar Albelad Press: Jeddah, 1987. (In Arabic.) 
[8] Duncan, G., The planning and development of the city of Jeddah, 1970-1984. Thesis, Durham University. http://etheses.dur.ac.uk/7069/. Accessed on: 20 Mar. 2020.

[9] Orbasli, A., Tourists in Historic Towns: Urban Conservation and Heritage Management, Routledge: Abingdon, Oxon, 2016.

[10] Tyler, N., Tyler, N., Tyler, I.R. \& Ligibel, T., Historic Preservation: An Introduction to its History, Principles, and Practice, W.W. Norton: New York, 2018.

[11] Saudi Press Agency (WAS), The crown-prince supports historic Jeddah building preservations with 50 million riyals. www.al-madina.com/article/630679. Accessed on: 20 March. 2020. (In Arabic.)

[12] Rahman, N.A., Shamsuddin, S. \& Ghani, I., What makes people use the street? Proceedings of the Towards a Livable Urban Environment in Kuala Lumpur City Centre Conference, Elsevier, 2015.

[13] Allison, E. \& Peters, L., Historic Preservation and The Livable City, Wiley: Hoboken, 2011.

[14] Shamsuddin, S. \& Sulaiman, A.B., The importance of conserving the old town centre in achieving a sustainable built environment of the future. Proceedings of The National Seminar on Built Environment: Sustainability through Management and Technology, Elsevier, 2002.

[15] Al-Gilani, A.A., Understanding the image of the Islamic urban landscape. University of Colorado at Denver and Health Sciences Center: Denver, 2005.

[16] Ashe, M., How to make AlBalad spaces livable. Graduation project, Jeddah, Department of Landscape Architecture, King Abdulaziz University, 2019.

[17] Saudi Press Agency (WAS), Cabinet meeting decrees. www.spa.gov.sa/viewstory.php ?lang=en\&newsid=2074681. Accessed on: 14 Apr. 2020. (In Arabic.)

[18] Al-Kinani, M., Jeddah bids farewell to art loving Mayer Mohammed Said Farsi, who transformed the city. www.arabnews.com/node/1462126/saudi-arabia. Accessed on: 6 Mar. 2020. 